\title{
MONITORING SPATIAL VARIATION IN TRIBAL POPULATION AT TAHSILS OF AHMEDNAGAR DISTRICT, MAHARASHTRA USING GIS TECHNIQUE
}

\author{
S. Deshmukh \\ Department of Economics, Modern College of Arts, Science and Commerce, Shivajinagar, Pune, India - \\ deshmukhsuresh5@gmail.com
}

Commission V, WG V/7 \& Commission IV, WG IV/6

KEY WORDS: Environment, Geographical Information System, Population, Socio-Economic, Spatio-Temporal, Tribal

\begin{abstract}
:
The tribal population represents a heterogeneous group scattered in different regions of India. The differences are noticed in language, cultural practices, socio-economic status and pattern of livelihood. The tribal population in India rapidly increased from 30.1 million in 1961 to 104.3 million in 2011. For same period tribal residing in rural area have increased by three times from 29.4 million to 93.8 million respectively. The tribal population resides in urban area is very less in number due to these pe ople like to live in the remote areas of the proximity of natural environment. In Maharashtra, more than 47 indigenous tribes were dwelling at Sahyadri and Satpuda mountainous ranges. According to 2011 census, there are about 1, 05, 10,213 tribal populations living in Maharashtra, which constitutes $10.05 \%$ population of state. In Maharashtra, there is regional disparity in tribal population such as Nandurbar District has the highest tribal concentration while Dhule, Gadchiroli, Nasik, and Ahmednagar District have moderate tribal concentration. Therefore, present research work is an attempt to understand the Spatio-temporal variation in tribal population of Ahmednagar district using GIS technique during the period of 2001-2011. This study is to examine the tahsil-wise tribal population and identifying pattern of tribal population density in Ahmednagar District. The result shows that more than $80 \%$ of tribal population concentrated in Akole, Sangamner, and Rahuri tahsil due to hilly region, roughed terrain, river basin, and forest area. It is also demonstrated that the planning control, researchers and decision-makers should be focused on these areas for implementing policies and large numbers of tribal can be benefited.
\end{abstract}

\section{INTRODUCTION}

It is estimated that there are 370 million indigenous people living on the surface of the earth across 70 countries (Paltasingh and Paliwal, 2014). These tribes are located mainly in Central Africa, South America, Oceania, India and Australia. It is noted that, tribes are indigenous part of Indian subcontinent because India is one of the largest tribal population countries in the world (Ali and Das, 2003). The tribes constitute nine percent of the country's total population, which ranks second in concern of tribal population world after Africa continent (Muzumdar, 1973). Tribal population in India is unevenly distributed. The tribal communities live in about 15 percent area of the country, in various ecological and geoclimatic conditions ranging from plains and forests to hills and inaccessible areas (Ambagudia, 2010). In 2001, Census enumeration tribal population was 8.43 crores and 8.2 percent of total population of the country. The tribal population of India, according to 2011 Census is 10.45 crores, constituting 8.63 percent of total population of country (Paltasingh and Paliwal, 2014).

In Maharashtra, several tribes are found i.e. Warli, Katkari, Kokana, Mahadeo Koli, Bhil, Thakar, Andha, Gond, Kolam, Oranon, Paradhi, Halaba, and Tokre Koli dwell in certain pockets. Forests and Mountains play vital role of magnet for tribals. Therefore, majority of tribals were found in Sahyadri, Satpuda mountainous ranges (Kokate and Solunke, 2011). In Maharashtra, more than 47 indigenous tribes were dwelling. According to 2011 census, there are about 1, 05, 10,213 tribal populations living in Maharashtra, which constitutes 10.05 percent population of state. In Maharashtra, Nandurbar District has highest tribal concentration i.e. 69.3 percent of district's total population; while Dhule, Gadchiroli and Nasik Districts have moderate tribal concentration i.e. between 25-50 percent of district's total population. Districts Nashik, Thane, Nandurbar, Dhule and Jalgaon contribute more than 50 percent to the state's tribal population. Overall sex ratios among tribals are 977 . The child sex ratio is 955; it is lowest in Kolhapur District (870) and highest in Gadchiroli District (985). Literacy rate among tribal's are 65.7 percent and among males and females, 74.3 percent and 57 percent respectively.

Therefore, present research work is an attempt to understand the spatio-temporal variation in tribal population of Ahmednagar district during 2001-2011. This study is to examine the tahsil-wise tribal population and identifying pattern of population density in Ahmednagar District during 2001 to 2011. Ahmednagar District is socio-economically one of the developed districts in Maharashtra.

\section{STUDY AREA}

Ahmednagar District popularly known as 'Nagar' is one of the important district of Western Maharashtra, which is situated partly in the upper Godavari basin and partly in the Bhima basin. It lies between $18^{\circ} 2^{\prime}$ to $19^{\circ} 9^{\prime} \mathrm{N}$ latitudes and $73^{\circ} 9^{\prime}$ to $75^{\circ} 5^{\prime} \mathrm{E}$ longitudes with the total geographical area of 17410.91 square kilometers (Wayal et al., 2016). Ahmednagar District is the largest district by area in the state of Maharashtra. Ahmednagar District has 1584 villages, 1 municipal corporation, 9 municipal council, 4041 grampanchayat, 18 urban centers and 1 cantonment board. The district is consisting of 14 revenue tahsil's namely Nagar, 
Parner, Pathardi, Newasa, Shrirampur, Shevgoan, Rahuri, Rahata, Sangamner, Kopargaon, Akole, Shrigonda, Jamkhed, Karjat (Figure 1).

According to 2011, Census of India the total population of Ahmednagar District was 45,43,159 in which male and female were $23,42,825$ and $22,00,334$ respectively. Parner is the largest tahsil by area with 1930.28 square kilometers while Srirampur is the smallest taluka with 569.87 square kilometers in the district. It is bounded on the north by Nasik District, Aurangabad District to the northeast side, Beed District to the east, Osmanabad and Solapur District to the south, Pune District to the west and Thane District to the north-west (Narke and Kore, 2012).

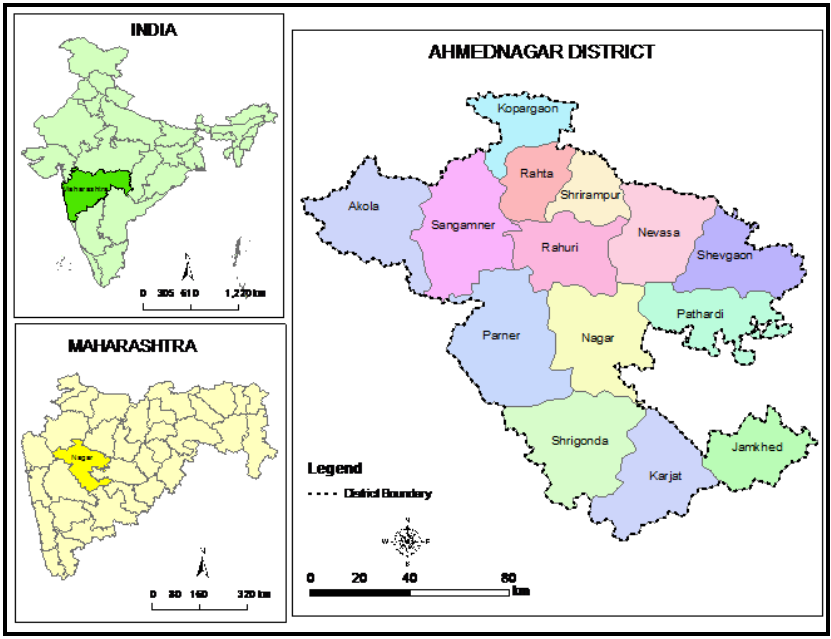

Figure 1. Location Map of Study Area

\section{OBJECTIVE}

The main objective of the present research work is to understand the spatial variation in tribal population of Ahmednagar District.

\section{MATERIALS AND METHODS}

This study is based on secondary data obtained mainly from the publications of Census of India. The main census publications of different periods of time from where data has been collected include the General Population Tables, Socio Cultural Tables, District Census Handbooks of Ahmednagar Districts, Primary Census Abstract, Final Population Tables etc. In addition to the sources indicated above, information and data have been collected from the Gokhale Institute of Politics and Economics, Pune and Statistical Department, Ahmednagar District. The collected data has been processed and analyzed by using different quantitative, statistical technique. A large number of books, research studies including dissertations, published and unpublished works from different sources have been studied thoroughly for the present study. Relevant web sites were visited from time to time for authentic information and data.

The present research work is an attempt to monitor the pattern of tribal population density of Ahmednagar District during 2001-2011. Population density refers to the ratio between numbers of people to the size of land in a country (Rai, 1996). It is usually measured in persons per sq $\mathrm{km}$ with applying following formula (Trewartha, 1953; Clarke, 1965; Sundaram, 1985; Ghosh, 1998; Sawant and Athawale, 1994; Chandana, 2004):

Density of Population $=$ Total Population/ Total Geographical Area

Tahsil has been considered to be the most appropriate unit of study for which data are available. There were 14 Tahsils in the district in 2011.

\section{RESULTS AND DISCUSSIONS}

The District level distribution of tribal population shows wide variation. Ahmednagar district is habitat of 8.33 percent tribal population of Maharashtra (See in Table 1). The largest cluster of tribal population in Ahmednagar district lies in upper Mula and Pravara basin and partially in Godavari river basin and Western part of Sahyadri Mountain (Pawar, 2015).

The rim of Sahyadri continuously encourages aboriginals to settle and survive. Dense forest, Hill valley, rugged topography, steep slopes support tribal communities. Most of the tribal are concentrated in western part of Akole Tahsil. Out of total tribal population of district, more than 36 percent tribals inhabit in Akole Tahsil. In Akole Tahsil itself, out of total population 45.59 and 47.86 percent population consists of tribals in 2001 and 2011 respectively (See in Table 1; Figure $2 \&$ Figure 3). Therefore, Government has declared Akole Tahsil as Tribal Sub Plan (TSP) area.

It is very interesting to note that more than 80 percent tribal population of district is concentrated in only 4 Tahsils like Akole (47.86 percent) Sangamner (10.59 percent), Kopargaon (11.37 percent) and Rahuri (10.54 percent) Tahsils in 2011 (See in Figure 3). Because of tribal population concentration are characterized by hilly, roughed terrain, forested and river basin. Distribution pattern of tribal population in Ahmednagar district is very uneven. In 2011, ten Tahsils mainly in South and East direction except Parner and Rahata falls in low percentage category ( 1 to 10 percent) of tribal distribution. In this first group Jamkhed with 1.43 percent, tribal population shows lowest in district, On the other hand, some parts of Shrirampur Tahsil stands on top with 6.80 percent tribes. Tahsils with less tribal population are characterized by relatively low attitude and thin vegetative cover area towards East and South of district. In next category Kopargaon, Sangamner and Rahuri Tahsil exhibit 11.37 percent, 10.59 percent and 10.54 percent respectively (See in Figure 3). Therefore, it comes into significant (10 to 20 percent) category of tribal distribution. These Tahsils are characterized by fluvial topography of Mula \& Pravara basin and partially Godavari River basin. Rahuri and Sangamner are covered by Baleshwar range and Mula and Pravara basin.

Such hill valley landscape is supreme location for tribes. Godavari River flows through Kopargaon Tahsil and there are hardly any shrubs and vegetative cover, which support to tribals. This Tahsil is neighbored by Nasik District from West and North sides, which is well-known for its tribal population. This vicinity of tribal belt of Nasik is also important reason for high tribal concentration in Kopargaon Tahsil. In Ahmednagar District, only Akole Tahsil comes in important (20 to $50 \%$ ) 
percentage category of tribal population. Out of total tribal population of district more than 37 percent, tribal population resides only in Akole Tahsil. Scheduled tribe Population Density of Ahmednagar District was never cross the state average from the period of 2001 to 2011 (See in Table 2). In 2001 , the ST population density in the region was 17.42 persons per sq $\mathrm{km}$, which has increased to 21.72 persons in last decades. According to Census of India, the highest population density was observed in Akole (80.77 \& 92.84 person per sq. km) Tahsil in 2001 and 2011 respectively due hilly region and lowest population density was recorded in Karjat Tahsil was 1.54 person per sq. km in 2001 and 2.30 per sq. $\mathrm{km}$ in 2011, due to plain areas (Table 2).

Similarly in 2001 the highest density was recorded in Akole Tahsil with 88.77 persons per sq. km followed by Kopargaon, Rahuri, Shrirampur, Sangamner Tahsils with 37.86, 26.97, 24.60 and 24.22 persons per sq. $\mathrm{km}$. respectively. In similarly Karjat Tahsil has recorded lowest density with 1.54 persons per sq. km after that, Jamkhed, Pathardi, Shevgaon and Shrigonda Tahsils (See in Table 2).

According to census 2011, tahsil-wise density clearly shows that Akole tahsil with has recorded the maximum density with 92.84 persons per sq. km followed by Kopargaon, Shrirampur, Rahuri, Sangamner Tahsils with 47.41, 34.32, 32.88 and 30.29 persons per sq. $\mathrm{km}$. respectively. This is mainly due to the increase in irrigated area, expansion of infrastructural facilities, as well as the implementation of developmental activities. The Karjat Tahsil has recorded the minimum density with 2.30 persons per sq. km, later on Jamkhed (2.59), Pathardi (3.39) and Shevgaon Tahsils (4.54 persons per sq. $\mathrm{km})$ due to undulating surface of low accessibility and developmental programmes are not properly implemented in these areas.

There is a found a high variation in spatio temporal changes in the tribal population density. The researchers observed that the death rate is rapidly declined in tribal region due to increase medical facilities in remote areas. Hence, population increased in tremendous proportion, as well as the density of population in tribal areas as affected. In 2001, the population density in the region was 17.42 persons per sq $\mathrm{km}$, which has increased to 21.72 persons just in last one decade (See in Table 2).

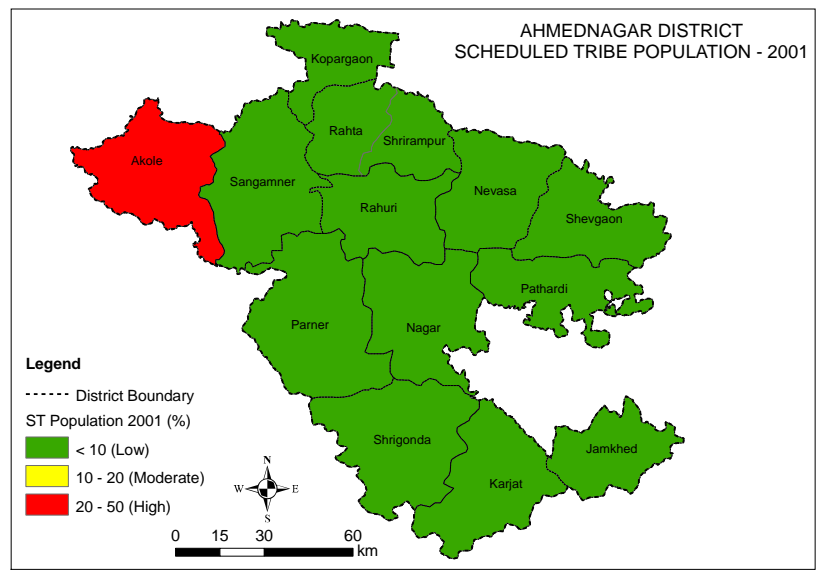

Figure 2. Scheduled Tribe population in Ahmednagar District, 2001

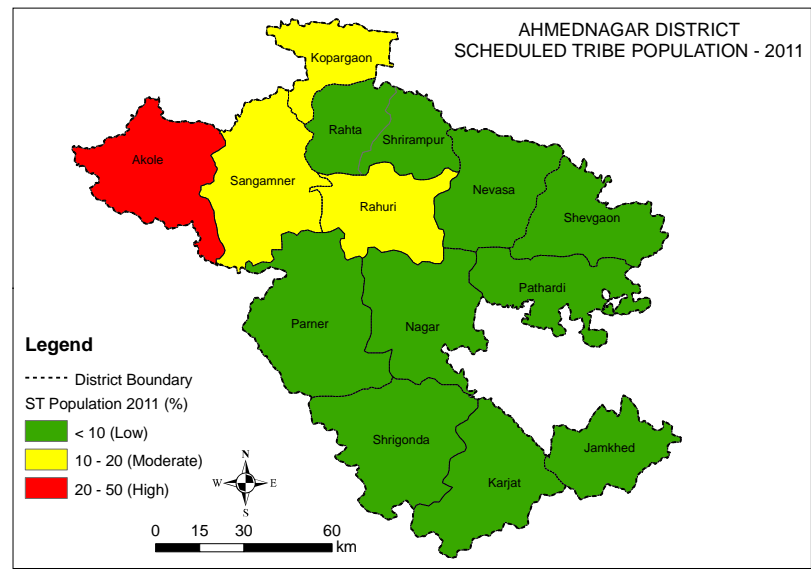

Figure 3. Scheduled Tribe population in Ahmednagar District, 2011

\section{CONCLUSIONS}

The density of scheduled tribe population in Ahmednagar District is considered, the increasing trend from 2001-2011 is observed due to some operatic changes are occurs. It was noted that 17.42 persons per sq $\mathrm{km}$ in 2001 , where as 21.72 persons per sq $\mathrm{km}$. in 2011. Density of Tribal people is marked increasing trend since last 10 years. There is a great variation in tribal density pattern of Scheduled tribal population in the study area. Population distribution denotes the spatial pattern due to dispersion of population, formation of agglomeration, linear spread etc.

It is observed that, the tribal population is mainly concentrated in such areas, which are highly under forest that can provide sustainability to them. It is evidenced from the study; the tribal population is inhabited in hilly, rough and tough areas like Akole Tahsil. It is suggested that, socio-economic development planning should take place in those areas where the problem is serious and large number of tribal can be benefited. In the context, the result of the present research work proves of immense importance for planners, researchers, administrator, educationist and decision makers.

\section{REFERENCES}

Ali, I., Das, I., 2003: Tribal Situation in North East India, Studies of Tribes Tribals, 1 (2), 141-148.

Ambagudia, J., 2010: Tribal Rights, Dispossession and the State in Orissa, Economic \& Political Weekly, xlv (33), 60-67.

Census of India. 2001 \& 2011: District Census Handbook Ahmednagar District.

Chandana, R. C., 2004: Geography of Population Concept Determinants and Pattern, Kalyani Publishers Pvt. Ltd., New Delhi.

Clarke, J. I., 1965: Population Geography, Pergamon Press, Oxford, 1- 6.

Ghosh, B. N., 1998: Fundamentals of Geography of Population, Sterling Publisher Pvt. Ltd. New Delhi, 28. 
Kokate, C. N., Solunke, R. S., 2011: The Tribal Development in Maharashtra-A Case Study. Research, Analysis and Evaluation, 1 (17), 9-71.

Muzumdar, K., 1973: Distribution of Tribal Population in Eastern Gujarat, The National Geographical Journal of India, XIV (Parts 3\& 4), 177.

Narke, S. Y., Kore, N. S., 2012: Trend of literacy pattern in Ahmednagar District (Maharashtra), Ultra Scientist, 24 (1B), 203-209.

Paltasingh, T., Paliwal, G., 2014: Tribal Population In India: Regional Dimensions \& Imperatives, Journal of Regional Development and Planning, 3 (2), 27-36.

Pawar, R.S., 2015: A Geographical Study of Concentration of Tribal Population and Their Literacy in Akole Tahsil, District Ahmednagar (MS), International Journal of Science and Research (IJSR), 4 (4), 2924-2928.

Rai, S., 1996: Pattern of Population Density in an Indian City, National Geographical Journal of India, 42(3 \& 4), 237-247.
Sawant, S. B., Athawale, A. S., 1994: Population Geography, Metha Publishing House, Pune, 37-40.

Sundaram, K.V., 1985: Population Geography, Contribution to Indian Geographer -VI (Ed).

Trewartha, G. T., 1953: A Case for Population Geography', Annals of the Association of American Geographers, 43, 79-97.

Wayal N., Mundhe N., Deshmukh S., 2016: Identifying SpatioTemporal Pattern of Literacy in Ahmednagar District,

International Journal of Recent Scientific Research, 7 (12), 14664-14669.

\section{Website Links}

http://censusindia.gov.in/ http://en.wikipedia.org/wiki/Maharashtra. https://mahasdb.maharashtra.gov.in https://en.wikipedia.org/wiki/Talukas_of_Ahmednagar_district

\section{ANNEX}

\begin{tabular}{|c|l|c|c|c|c|c|c|c|}
\hline $\begin{array}{c}\text { Sr. } \\
\text { No. }\end{array}$ & $\begin{array}{c}\text { Name of } \\
\text { Tahsil }\end{array}$ & \multicolumn{2}{|c|}{$\begin{array}{c}\text { Total } \\
\text { Population }\end{array}$} & \multicolumn{2}{c|}{$\begin{array}{c}\text { S. T. } \\
\text { Population }\end{array}$} & $\begin{array}{c}\text { S.T. Population } \\
(\%)\end{array}$ & $\begin{array}{c}\text { Decadal Change } \\
\text { in Tribal } \\
\text { Population (\%) }\end{array}$ \\
\hline & & $\mathbf{2 0 0 1}$ & $\mathbf{2 0 1 1}$ & $\mathbf{2 0 0 1}$ & $\mathbf{2 0 1 1}$ & $\mathbf{2 0 0 1}$ & $\mathbf{2 0 1 1}$ & $\mathbf{2 0 0 1 - 2 0 1 1}$ \\
\hline 1 & Akole & 266638 & 291950 & 121566 & 139730 & 45.59 & 47.86 & 4.98 \\
\hline 2 & Jamkhed & 134216 & 158380 & 1879 & 2272 & 1.40 & 1.43 & 2.47 \\
\hline 3 & Karjat & 205674 & 235792 & 2310 & 3464 & 1.12 & 1.47 & 30.80 \\
\hline 4 & Kopargaon & 277170 & 302452 & 27457 & 34377 & 9.91 & 11.37 & 14.74 \\
\hline 5 & Nagar & 606690 & 684044 & 10208 & 14396 & 1.68 & 2.10 & 25.08 \\
\hline 6 & Nevasa & 326698 & 357829 & 15720 & 18894 & 4.81 & 5.28 & 9.73 \\
\hline 7 & Parner & 246552 & 274167 & 12074 & 17054 & 4.90 & 6.22 & 27.02 \\
\hline 8 & Pathardi & 214872 & 258109 & 2712 & 4118 & 1.26 & 1.60 & 26.41 \\
\hline 9 & Rahta & 288279 & 320485 & 15425 & 20130 & 5.35 & 6.28 & 17.39 \\
\hline 10 & Rahuri & 294924 & 322823 & 27913 & 34036 & 9.46 & 10.54 & 11.40 \\
\hline 11 & Sangamner & 441439 & 487939 & 41297 & 51652 & 9.36 & 10.59 & 13.16 \\
\hline 12 & Shevgaon & 203676 & 245714 & 3277 & 4681 & 1.61 & 1.91 & 18.41 \\
\hline 13 & Shrigonda & 277356 & 315975 & 7401 & 13870 & 2.67 & 4.39 & 64.50 \\
\hline 14 & Shrirampur & 256458 & 287500 & 14016 & 19556 & 5.47 & 6.80 & 24.46 \\
\hline \multicolumn{1}{|c|}{ District Total } & $\mathbf{4 0 4 0 6 4 2}$ & $\mathbf{4 5 4 3 1 5 9}$ & $\mathbf{3 0 3 2 5 5}$ & $\mathbf{3 7 8 2 3 0}$ & $\mathbf{7 . 5 1}$ & $\mathbf{8 . 3 3}$ & $\mathbf{1 0 . 9 3}$ \\
\hline
\end{tabular}

Source: District Census Handbook, Ahmednagar (M.S.) (2001 \& 2011)

Table 1. Distribution of Scheduled Tribe in Ahmednagar District 


\begin{tabular}{|c|l|c|c|c|c|}
\hline $\begin{array}{c}\text { Sr. } \\
\text { No. }\end{array}$ & $\begin{array}{c}\text { Name of } \\
\text { Tahsil }\end{array}$ & $\begin{array}{c}\text { Geographical } \\
\text { Area (km2) }\end{array}$ & \multicolumn{2}{|c|}{$\begin{array}{c}\text { Population } \\
\text { Density } \\
\text { (Sq. km) }\end{array}$} & $\begin{array}{c}\text { Decadal Change in S.T. } \\
\text { Population Density (\%) }\end{array}$ \\
\hline & & & $\mathbf{2 0 0 1}$ & $\mathbf{2 0 1 1}$ & $\mathbf{2 0 0 1 - 2 0 1 1}$ \\
\hline 1 & Akole & 1505.08 & 80.77 & 92.84 & 14.94 \\
\hline 2 & Jamkhed & 878.62 & 2.14 & 2.59 & 20.92 \\
\hline 3 & Karjat & 1503.61 & 1.54 & 2.30 & 49.96 \\
\hline 4 & Kopargaon & 725.16 & 37.86 & 47.41 & 25.20 \\
\hline 5 & Nagar & 1605.74 & 6.36 & 8.97 & 41.03 \\
\hline 6 & Nevasa & 1343.43 & 11.70 & 14.06 & 20.19 \\
\hline 7 & Parner & 1930.28 & 6.26 & 8.83 & 41.25 \\
\hline 8 & Pathardi & 1214.1 & 2.23 & 3.39 & 51.84 \\
\hline 9 & Rahta & 759.19 & 20.32 & 26.52 & 30.50 \\
\hline 10 & Rahuri & 1035.11 & 26.97 & 32.88 & 21.94 \\
\hline 11 & Sangamner & 1705.06 & 24.22 & 30.29 & 25.07 \\
\hline 12 & Shevgaon & 1031.85 & 3.18 & 4.54 & 42.84 \\
\hline 13 & Shrigonda & 1603.81 & 4.61 & 8.65 & 87.41 \\
\hline 14 & Shrirampur & 569.87 & 24.60 & 34.32 & 39.53 \\
\hline \multicolumn{2}{|c|}{ District Total } & $\mathbf{1 7 4 1 0 . 9 1}$ & $\mathbf{1 7 . 4 2}$ & $\mathbf{2 1 . 7 2}$ & $\mathbf{2 4 . 7 2}$ \\
\hline
\end{tabular}

Source: District Census Handbook, Ahmednagar (M.S.) (2001 \& 2011)

Table 2. Changes in Tribal Population Density in Ahmednagar District (2001-2011) 